\title{
Alkaloid Enantiomers from the Roots of Isatis indigotica
}

\author{
Dongdong Zhang ${ }^{1} \mathbb{C}$, Yanhong Shi ${ }^{2}$, Rui Xu ${ }^{1}$, Kang Du ${ }^{1}$, Fujiang Guo ${ }^{1}$, Kaixian Chen ${ }^{1,3}$,

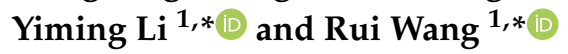 \\ 1 School of Pharmacy, Shanghai University of Traditional Chinese Medicine, Shanghai 201203, China \\ 2 Institute of TCM International Standardization of Shanghai University of Traditional Chinese Medicine, \\ Shanghai 201203, China \\ 3 Shanghai Institute of Materia Medica, Chinese Academy of Science, Shanghai 201203, China \\ * Correspondence: ymlius@163.com (Y.L.); wr@shutcm.edu.cn (R.W.); Tel.: +86-215-132-2191 (Y.L.); \\ +86-215-132-2181 (R.W.); Fax: +86-215-132-2193 (Y.L. \& R.W.)
}

Received: 20 July 2019; Accepted: 28 August 2019; Published: 29 August 2019

\begin{abstract}
Five pairs of alkaloid enantiomers $(\mathbf{1} \mathbf{a} / \mathbf{1} \mathbf{b}-\mathbf{5} \mathbf{a} / \mathbf{5 b})$ were obtained from Isatis indigotica (I. indigotica) roots. Among them, $\mathbf{1} \mathbf{a} / \mathbf{1} \mathbf{b}, \mathbf{2} \mathbf{a} / \mathbf{2} \mathbf{b}$ and $\mathbf{3 a} \mathbf{3} \mathbf{3} \mathbf{b}$ were determined as three pairs of new alkaloid enantiomers. Their structures were elucidated by physicochemical properties and spectroscopic methods. The absolute configurations were deduced by comparison of their experimental circular dichroism (CD) and calculated electronic circular dichroism (ECD) spectra, as well as by single-crystal $\mathrm{X}$-ray crystallography using anomalous scattering of $\mathrm{Cu} \mathrm{K} \alpha$ radiation. Alkaloids $\mathbf{1 a}$ and $\mathbf{1 b}$ possess an unpresented carbon skeleton and their putative biosynthetic pathways are discussed. Moreover, all of the alkaloids were tested for their nitric oxide (NO) inhibitory effects in RAW 264.7 cells, and 4a and $4 \mathrm{~b}$ showed inhibitory effects with $\mathrm{IC}_{50}$ values of $76.97 \mu \mathrm{M}$ and $65.88 \mu \mathrm{M}$, respectively.
\end{abstract}

Keywords: Isatis indigotica; alkaloid enantiomers; structure deduction; anti-inflammatory activity

\section{Introduction}

"Ban lan gen", widely distributed and cultivated in the North of China, is the roots of Isatis indigotica Fort. (Cruciferae) [1-3]. As one of the most famous traditional Chinese medicines (TCMs), ban lan gen is usually used for the treatment of various kinds of diseases, such as influenza, fever, epidemic hepatitis and infections [4-6]. Previous phytochemical investigations of I. indigotica have led to the isolation of various kinds of natural constituents, including alkaloids, lignans, flavonoids and nucleotides [1-9], among which alkaloids have been considered as the most active constituents that possess anti-inflammatory, antiviral, antibacterial, antitumor and antioxidant activities [1,4-9]. For our continuous project to explore more bioactive components from I. indigotica [8,9], five pairs of alkaloid enantiomers were isolated from the $80 \%$ alcohol exact of $I$. indigotica roots. Among them, 1a/1b, $\mathbf{2} a / 2 b$ and $\mathbf{3 a} / \mathbf{3 b}$ were determined as three pairs of new enantiomers, whose structures and absolute configurations were determined by extensive spectroscopic data analysis, including 1D, 2D-NMR and HRESIMS data, optical rotation data, comparison of their experimental circular dichroism (CD) and calculated electronic circular dichroism (ECD) spectra and single-crystal X-ray crystallography using anomalous scattering of $\mathrm{Cu} \mathrm{K} \alpha$ radiation. The known forms $(\mathbf{4 a} / \mathbf{4} \mathbf{b}-\mathbf{5 a} / \mathbf{5 b}$, Figure 1$)$ were identified by comparison of their spectroscopic and optical rotation data with those reported in the literature as (-)-(2R,3R)-3-hydroxy-2H-pyrrolo[2-b]indolo[5,5a,6-b,a]quinazoline- $9(8 H), 7^{\prime}$-dione (4a) [1], (+)-(2S,3S)-3-hydroxy-2H-pyrrolo[2-b]indolo[5,5a,6-b,a]quinazoline-9(8H),7'-dione (4b) [1], epigoitrin (5a) [10] and goitrin (5b) [10]. Alkaloids are one of the main types of active constituents in I. indigotica, and they have been reported to possess potential anti-inflammatory effects [1-10]. 
This pharmacological action, together with the traditional use for the treatment of epidemic hepatitis, prompted us to test the inhibitory effects on nitric oxide (NO) production of all the isolated alkaloids $(\mathbf{1} \mathbf{a} / \mathbf{1} b-\mathbf{5 a} / \mathbf{5 b})$. Herein, the isolation and structure elucidation, putative biosynthetic pathways and the $\mathrm{NO}$ inhibitory activities of these enantiomers are presented.

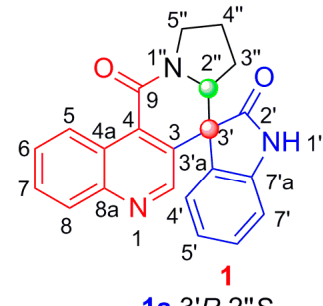

1a 3 ' $R, 2$ "S 1 b 3 'S, 2"R

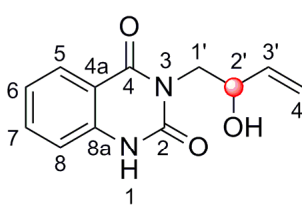

2

2a 2 'R

2b 2 'S

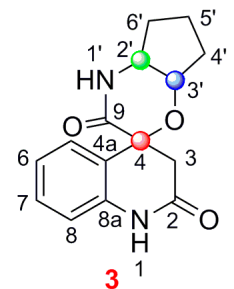

3a $4 S, 2^{\prime} R, 3^{\prime} R$ 3b $4 R, 2 ' S, 3$ 'S

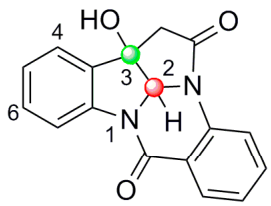

4

4a $2 R, 3 R$

4b $2 S, 3 S$

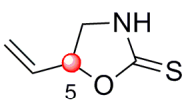

5

5a $5 R$

5b $5 S$

Figure 1. Structures of compounds $1 \mathrm{a} / \mathbf{1} \mathbf{b}-\mathbf{5} \mathbf{a} / \mathbf{5 b}$.

\section{Results and Discussion}

Isatisindigoticanine B (1) was obtained as a primrose yellow amorphous power. Its molecular formula was determined as $\mathrm{C}_{22} \mathrm{H}_{17} \mathrm{~N}_{3} \mathrm{O}_{2}$, by the ${ }^{13} \mathrm{C}$ NMR data and the HRESIMS quasimolecular ion peak at $m / z 356.1398[\mathrm{M}+\mathrm{H}]^{+}\left(\right.$cacld. $\left.356.1394[\mathrm{M}+\mathrm{H}]^{+}\right)$. The ${ }^{1} \mathrm{H}$ NMR spectrum (Table 1$)$ of 1 showed signals of two ortho-disubstituted benzene ring at $\left[\delta_{\mathrm{H}} 9.29(1 \mathrm{H}, \mathrm{d}, J=8.6 \mathrm{~Hz}, \mathrm{H}-5), 7.77(1 \mathrm{H}\right.$, $\mathrm{dd}, J=8.6,7.7 \mathrm{~Hz}, \mathrm{H}-6), 7.84(1 \mathrm{H}, \mathrm{dd}, J=8.3,7.7 \mathrm{~Hz}, \mathrm{H}-7)$ and $8.07(1 \mathrm{H}, \mathrm{d}, J=8.3 \mathrm{~Hz}, \mathrm{H}-8)]$ and [6.76 $\left(1 \mathrm{H}, \mathrm{d}, J=7.5 \mathrm{~Hz}, \mathrm{H}-4^{\prime}\right), 6.95\left(1 \mathrm{H}, \mathrm{dd}, J=7.7,7.5 \mathrm{~Hz}, \mathrm{H}-5^{\prime}\right), 7.30\left(1 \mathrm{H}, \mathrm{dd}, J=7.8,7.7 \mathrm{~Hz}, \mathrm{H}-6^{\prime}\right)$ and 7.05 $\left.\left(1 \mathrm{H}, \mathrm{d}, J=7.8 \mathrm{~Hz}, \mathrm{H}-7^{\prime}\right)\right]$; a trisubstituted double bond at $\delta_{\mathrm{H}} 8.56(1 \mathrm{H}, \mathrm{s}, \mathrm{H}-2)$ and an exchangeable proton at $\delta_{\mathrm{H}} 11.25\left(1 \mathrm{H}\right.$, brs, NH-1'). The ${ }^{13} \mathrm{C}$ NMR spectrum (Table 1$)$ displayed 22 carbon signals, and based on the DEPT $135^{\circ}$ experiments, $9 \times \mathrm{C}$ signals at $\delta_{\mathrm{C}}(176.8,161.6,148.5,141.9,133.4,132.1,128.2$, $124.6,55.4), 10 \times \mathrm{CH}$ signals at $\delta_{\mathrm{C}}(148.3,130.4,130.1,129.8,128.9,126.7,124.4,123.1,111.2,61.8)$ and $3 \times \mathrm{CH}_{2}$ signals at $\delta_{\mathrm{C}}(46.6,27.1,22.8)$ were observed. These spectroscopic features, along with the molecular formula and the degrees of unsaturation (16 index of hydrogen deficiency, IHD), suggested that isatisindigoticanine B was an unusual alkaloid [1-3,6-9]. This inference was confirmed by detailed analysis of the 2D NMR data. The proton and protonated carbon resonances in the NMR spectra of 1 were unambiguously assigned by the HSQC experiments [11-14]. The ${ }^{1} \mathrm{H}-{ }^{1} \mathrm{H}$ COSY correlations of $\mathrm{H}-4^{\prime} / \mathrm{H}-5^{\prime} / \mathrm{H}-6^{\prime} / \mathrm{H}-7^{\prime}$, along with HMBC correlations (Figure 2) of NH-1'/C-2' , C-3' and C-7' a, indicate a $1 \mathrm{H}$-indol-2-one unit in $\mathbf{1}$ [15]; ${ }^{1} \mathrm{H}-{ }^{1} \mathrm{H}$ COSY correlations of $\mathrm{H}-2^{\prime \prime} / \mathrm{H}-3^{\prime \prime} / \mathrm{H}-4{ }^{\prime \prime} / \mathrm{H}-5^{\prime \prime}$, along with the HMBC correlations of $\mathrm{H}-2^{\prime \prime} / \mathrm{C}-3^{\prime \prime}$ and C-5", indicated a pyrrolidine unit in 1 [16]; ${ }^{1} \mathrm{H}-{ }^{1} \mathrm{H}$ COSY correlations of $\mathrm{H}-5 / \mathrm{H} 6 / \mathrm{H} 7 / \mathrm{H} 8$, along with the HMBC correlations of $\mathrm{H}-2 / \mathrm{C}-3$ and $\mathrm{C}-4, \mathrm{H}-5 / \mathrm{C}-4$ and C-8a and the remaining molecular formula $\mathrm{C}_{10} \mathrm{H}_{5} \mathrm{NO}$, indicated a 4-quinolinecarboxylic acid unit in 1 [17]. HMBC correlations of $\mathrm{H}-2 / \mathrm{C}-3^{\prime}, \mathrm{C}-3$ and $\mathrm{C}-4$ and correlations of $\mathrm{H}-2^{\prime \prime} / \mathrm{C}-9, \mathrm{C}-2^{\prime}, \mathrm{C}-3^{\prime}$ and C-5", determined the $1 \mathrm{H}$-indol-2-one unit connected with the pyrrolidine unit and the 4-quinolinecarboxylic acid via a six-membered ring of C-3-C-4-C-9-N-1" -C-2"-C-3'. The planar structure of 1 was thus deduced as depicted in Figure 1. Subsequent HPLC separation of $\mathbf{1}$ on a chiral column yielded $\mathbf{1 a}$ and $\mathbf{1 b}$ (Figure S34, Supplementary Information) with opposite optical rotations $\left(+12.6^{\circ}\right.$ for $1 \mathrm{a}$ and $-12.5^{\circ}$ for $\mathbf{1 b}$ ) and mirrored CD spectra curves (Figure 3). To further determine the absolute configurations of $\mathbf{1}$, the ECD curves were simulated for the four epimers of $\mathbf{1}$, [ $\left(3^{\prime} R, 2^{\prime \prime} S\right)-\mathbf{1},\left(3^{\prime} S, 2^{\prime \prime} R\right)-\mathbf{1},\left(3^{\prime} R, 2^{\prime \prime} R\right)-\mathbf{1}$ and $\left.\left(3^{\prime} S, 2^{\prime \prime} S\right)-1\right]$ (Figure 3$)$. The experimental CD spectra of $\mathbf{1 a}$ and $\mathbf{1} \mathbf{b}$ were well matched with the calculated ECD curves of $\left(3^{\prime} R, 2^{\prime \prime} S\right)-\mathbf{1}$ and $\left(3^{\prime} S, 2^{\prime \prime} R\right)-1$, respectively. Accordingly, the structure of $1 \mathbf{a}$ and $\mathbf{1 b}$ were elucidated as depicted (Figure 1$)$ and named as $(+)-\left(3^{\prime} R, 2^{\prime \prime} S\right)$-isatisindigoticanine B (1a) and $(-)-\left(3^{\prime} S, 2^{\prime \prime} R\right)$-isatisindigoticanine $\mathrm{B}(\mathbf{1 b})$. This carbon skeleton is the first report from a natural source and the putative biosynthetic pathways were proposed (Figure 4). 
Table 1. ${ }^{1} \mathrm{H}$ NMR (600 MHz in DMSO- $\left.d_{6}\right)$ and ${ }^{13} \mathrm{C}$ NMR data $\left(150 \mathrm{MHz}\right.$ in DMSO- $\left.d_{6}\right)$ of $\mathbf{1 a} \mathbf{a} \mathbf{1} \mathbf{b}-\mathbf{3 a} \mathbf{a} \mathbf{3}$ (ov: overlap signals).

\begin{tabular}{|c|c|c|c|c|c|c|}
\hline \multirow{2}{*}{ No. } & \multicolumn{2}{|l|}{$1 \mathrm{a} / \mathbf{1 b}$} & \multicolumn{2}{|l|}{$2 a / 2 b$} & \multicolumn{2}{|l|}{$3 a / 3 b$} \\
\hline & $\delta_{\mathrm{H}}(J$ in $\mathrm{Hz})$ & $\delta_{\mathrm{C}}$ & $\delta_{\mathrm{H}}(J$ in $\mathrm{Hz})$ & $\delta_{\mathrm{C}}$ & $\delta_{\mathrm{H}}(J$ in $\mathrm{Hz})$ & $\delta_{\mathrm{C}}$ \\
\hline 1 & & & 11.39, brs & & 12.39, brs & \\
\hline 2 & $8.56, \mathrm{~s}$ & 148.3 & & 150.8 & & 179.9 \\
\hline 3 & & 133.4 & & & $2.43,2 \mathrm{H}$, ov & 47.9 \\
\hline 4 & & 132.1 & & 162.6 & & 71.8 \\
\hline $4 a$ & & 124.6 & & 114.3 & & 131.7 \\
\hline 5 & $9.29, \mathrm{~d}(8.6)$ & 126.7 & $7.93, \mathrm{~d}(8.0)$ & 127.9 & 7.27, d (7.3) & 123.7 \\
\hline 6 & $7.77, \mathrm{dd}(8.6,7.7)$ & 128.9 & $7.22, \mathrm{dd}(8.0,7.7)$ & 122.9 & $6.87, \mathrm{dd}(7.5,7.3)$ & 121.9 \\
\hline 7 & $7.84, \mathrm{dd}(8.3,7.7)$ & 130.4 & 7.76 , dd $(8.2,7.7)$ & 135.4 & $7.17, \mathrm{dd}(7.7,7.5)$ & 128.5 \\
\hline 8 & $8.07, \mathrm{~d}(8.3)$ & 129.8 & $7.16, \mathrm{~d}(8.2)$ & 115.5 & $6.76, \mathrm{~d}(7.7)$ & 109.4 \\
\hline $8 a$ & & 148.5 & & 139.9 & & 141.3 \\
\hline 9 & & 161.6 & & & & 174.2 \\
\hline $1^{\prime}$ & $11.25, \mathrm{brs}$ & & $\begin{array}{l}3.84, \mathrm{dd}(12.6,5.0) \\
4.01, \mathrm{dd}(12.6,5.0)\end{array}$ & 45.6 & 10.37, brs & \\
\hline $2^{\prime}$ & & 176.8 & $4.34, \mathrm{dd}(12.6,6.5)$ & 69.2 & $3.33, \mathrm{~m}$ & 46.9 \\
\hline $3^{\prime}$ & & 55.4 & $5.83, \operatorname{ddd}(16.9,10.7,6.5)$ & 140.0 & $3.82, \mathrm{dd}(7.7,1.4)$ & 68.5 \\
\hline $3^{\prime} \mathrm{a}$ & & 128.2 & & & & \\
\hline $4^{\prime}$ & $6.76, d(7.5)$ & 124.4 & $\begin{array}{l}5.01, \mathrm{dd}(10.7,1.2) \\
5.11, \mathrm{dd}(16.9,1.2)\end{array}$ & 115.5 & $\begin{array}{l}1.71, \mathrm{~m} \\
1.90, \mathrm{~m}\end{array}$ & 31.8 \\
\hline $5^{\prime}$ & $6.95, \mathrm{dd}(7.7,7.5)$ & 123.1 & & & $1.73, \mathrm{~m} ; 1.99, \mathrm{~m}$ & 28.4 \\
\hline $6^{\prime}$ & $7.30, \mathrm{dd}(7.8,7.7)$ & 130.1 & & & $\begin{array}{c}2.28, \text { dd }(12.5,6.2) \\
2.43, \text { ov }\end{array}$ & 43.3 \\
\hline $7^{\prime}$ & $7.05, \mathrm{~d}(7.8)$ & 111.2 & & & & \\
\hline $7^{\prime} \mathrm{a}$ & & 141.9 & & & & \\
\hline $2^{\prime \prime}$ & $4.44, \mathrm{dd}(9.1,2.6)$ & 61.8 & & & & \\
\hline $3^{\prime \prime}$ & $1.11, \mathrm{~m} ; 1.97, \mathrm{~m}$ & 27.1 & & & & \\
\hline $4^{\prime \prime}$ & $1.94,2 \mathrm{H}, \mathrm{m}$ & 22.8 & & & & \\
\hline $5^{\prime \prime}$ & $3.48, \mathrm{ov} ; 3.81, \mathrm{~m}$ & 46.6 & & & & \\
\hline $2^{\prime}-\mathrm{OH}$ & & & $5.12, \mathrm{~d}(5.2)$ & & & \\
\hline
\end{tabular}

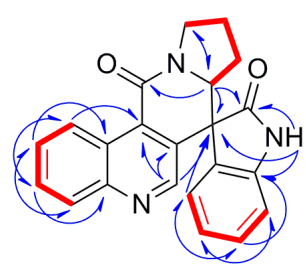

$1 \mathrm{a} / 1 \mathrm{~b}$

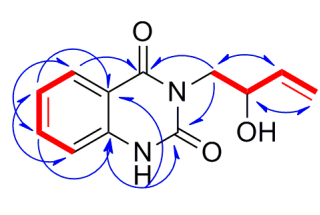

$2 a / 2 b$

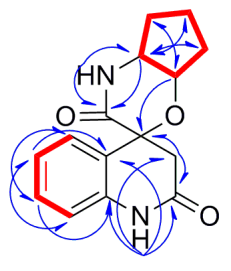

$3 a / 3 b$

$$
\text { - : }{ }^{1} \mathrm{H}-{ }^{1} \mathrm{H} \text { COSY } \mathrm{H} \mathrm{C}: \mathrm{HMBC}
$$

Figure 2. Key ${ }^{1} \mathrm{H}_{-}{ }^{1} \mathrm{H}$ COSY and HMBC correlations of compounds $\mathbf{1} \mathbf{a} / \mathbf{1} \mathbf{b}-\mathbf{3 a} / \mathbf{3} \mathbf{b}$.

Isatisindigoticanine $C(2)$ was obtained as a white amorphous power. Its molecular formula was assigned as $\mathrm{C}_{12} \mathrm{H}_{12} \mathrm{~N}_{2} \mathrm{O}_{3}$ by the 1D NMR data and the HRESIMS quasimolecular ion peak at $\mathrm{m} / z$ 231.0771 [M - H] $]^{-}$(cacld. $231.0775[\mathrm{M}-\mathrm{H}]^{-}$). The ${ }^{1} \mathrm{H}$ NMR spectrum (Table 1) of 2 showed signals of an ortho-disubstituted benzene ring at $\delta_{\mathrm{H}} 7.93(1 \mathrm{H}, \mathrm{d}, J=8.0 \mathrm{~Hz}, \mathrm{H}-5), 7.22(1 \mathrm{H}, \mathrm{dd}, J=8.0,7.7 \mathrm{~Hz}, \mathrm{H}-6)$, $7.76(1 \mathrm{H}, \mathrm{dd}, J=8.2,7.7 \mathrm{~Hz}, \mathrm{H}-7)$ and $7.16(1 \mathrm{H}, \mathrm{d}, J=8.2 \mathrm{~Hz}, \mathrm{H}-8)[8,9,15]$; a monosubstituted double bond at $\delta_{\mathrm{H}} 5.83\left(1 \mathrm{H}, \mathrm{ddd}, J=16.9,10.7,6.5 \mathrm{~Hz}, \mathrm{H}-3^{\prime}\right), 5.01\left(1 \mathrm{H}, \mathrm{dd}, J=10.7,1.2 \mathrm{~Hz}, \mathrm{H}-4^{\prime} \mathrm{a}\right)$ and $5.11(1 \mathrm{H}$, $\mathrm{dd}, J=16.9,1.2 \mathrm{~Hz}, \mathrm{H}-4^{\prime} \mathrm{b}$ ) and an exchangeable proton at $\delta_{\mathrm{H}} 11.39$ (brs, NH-1) [15]. Analysis of the ${ }^{13} \mathrm{C}$ NMR, DEPT $135^{\circ}$ and HSQC data (Table 1) of 2 , a $2^{\prime}$-hydroxybut-3'-en-1' -yl (45.6, $\mathrm{CH}_{2} ; 69.2, \mathrm{CH} ; 140.0$, $\left.\mathrm{CH} ; 115.5, \mathrm{CH}_{2}\right)[4,10]$ and a quinazoline-2,4(1H,3H)-dione moiety $(150.8, \mathrm{C} ; 162.6, \mathrm{C} ; 114.3, \mathrm{C} ; 127.9$, $\mathrm{CH} ; 122.9, \mathrm{CH} ; 135.4, \mathrm{CH} ; 115.5, \mathrm{CH} ; 139.9, \mathrm{C})$ were observed [1-3]. HMBC correlations of $\mathrm{H}-1^{\prime} / \mathrm{C}-2$ and C-4 indicated the $2^{\prime}$-hydroxybut- $3^{\prime}$-en- $1^{\prime}$-yl unit connected with the quinazoline-2,4(1H,3H)-dione unit via a N-3-C-1 bond $[2,3]$. This inference was supported by detailed analysis of the $2 \mathrm{D}$ NMR data 
including HSQC, HMBC (Figure 2) and ${ }^{1} \mathrm{H}-{ }^{1} \mathrm{H}$ COSY (Figure 2) experiments. The planar structure of 2 was thus deduced as depicted in Figure 1. Subsequent HPLC separation of 2 on a chiral column yielded $\mathbf{2 a}$ and $\mathbf{2} \mathbf{b}$ in a ratio of approximately $1: 1$, with opposite optical rotations $\left(-31.1^{\circ}\right.$ for $\mathbf{2 a}$ and $+33.1^{\circ}$ for $\mathbf{2 b}$ ) and cotton effects in their experimental ECD spectra (Figures S29 and S35, Supplementary Information). The comparison of the experimental CD spectra and the calculated ECD spectra of $\mathbf{2 a}$ and $\mathbf{2} \mathbf{b}$ (Figure 3 ) confirmed the two enantiomers as $(-)-\left(2^{\prime} R\right)$-isatisindigoticanine $C$ (2a, Figure 1$)$ and $(+)-\left(2^{\prime} S\right)$-isatisindigoticanine $C(\mathbf{2 b}$, Figure 1$)$, respectively [2,3]. Finally, a single-crystal $X$-ray experiment with $\mathrm{Cu} K \alpha$ radiation analysis confirmed the structure of $(+)-\left(2^{\prime} S\right)$-isatisindigoticanine $\mathrm{C}$ (2b, Figure 5).
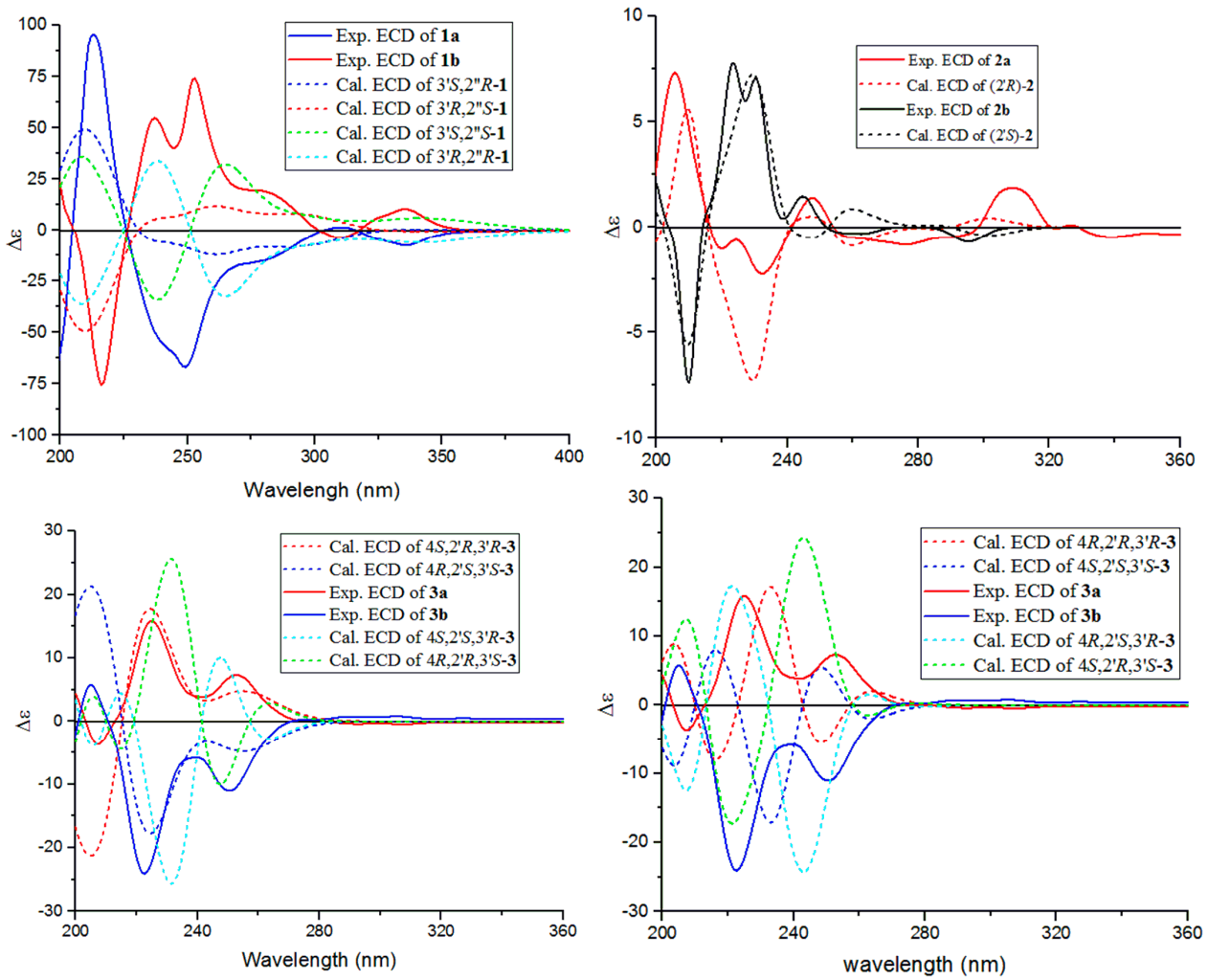

Figure 3. Experimental and calculated electronic circular dichroism (ECD) spectra of compounds $1 \mathrm{a} / \mathbf{1} \mathrm{b}-\mathbf{3 a} / \mathbf{3 b}$.

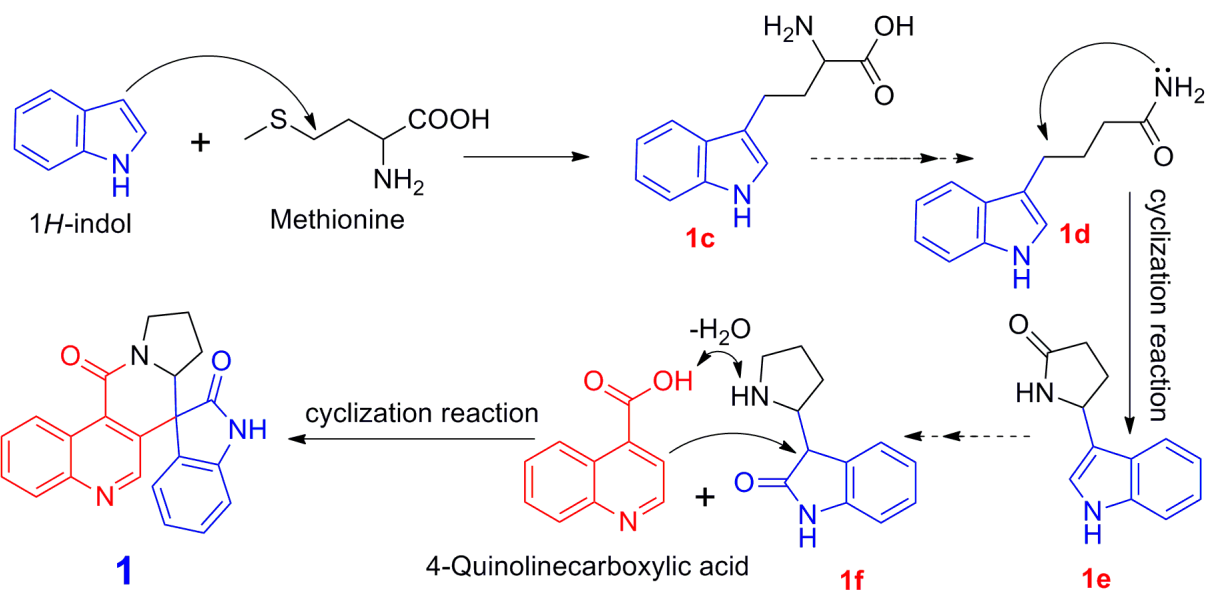

Figure 4. Putative biosynthetic pathway of compound 1. 


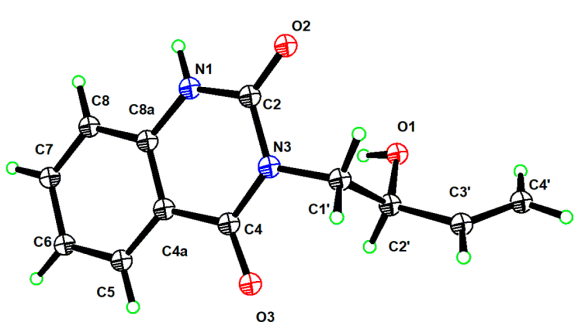

Figure 5. ORTEP darning of $(+)-\left(2^{\prime} S\right)$-isatisindigoticanine $C(\mathbf{2 b})$.

Isatisindigoticanine $\mathrm{D}(3)$, a white amorphous powder, has the molecular formula of $\mathrm{C}_{15} \mathrm{H}_{16} \mathrm{~N}_{2} \mathrm{O}_{3}$, which was supported by the positive HRESIMS ion at $m / z 273.1245[\mathrm{M}+\mathrm{H}]^{+}\left(\right.$cacld. $\left.273.1239[\mathrm{M}+\mathrm{H}]^{+}\right)$ and 1D NMR data. The ${ }^{1} \mathrm{H}$ NMR spectrum (Table 1) of 3 showed signals of an ortho-disubstituted benzene ring at $\delta_{\mathrm{H}} 7.27(1 \mathrm{H}, \mathrm{d}, J=7.3 \mathrm{~Hz}, \mathrm{H}-5), 6.87(1 \mathrm{H}, \mathrm{dd}, J=7.5,7.3 \mathrm{~Hz}, \mathrm{H}-6), 7.17(1 \mathrm{H}$, $\mathrm{dd}, J=7.7,7.5 \mathrm{~Hz}, \mathrm{H}-7)$ and $6.76(1 \mathrm{H}, \mathrm{d}, J=7.7 \mathrm{~Hz}, \mathrm{H}-8)$ and two exchangeable protons at $\delta_{\mathrm{H}}$ 12.39 (brs, NH-1) and 10.37 (brs, NH-1') [1,15]. The ${ }^{13} \mathrm{C}$ NMR spectrum (Table 1) displayed 15 carbon signals based on the DEPT $135^{\circ}$ experiments, and $5 \times \mathrm{C}$ signals at $\delta_{\mathrm{C}}(179.9,174.2,141.3$, $131.7,71.8), 6 \times \mathrm{CH}$ signals at $\delta_{\mathrm{C}}(128.5,123.7,121.9,109.4,68.5,46.9)$ and $4 \times \mathrm{CH}_{2}$ signals at $\delta_{\mathrm{C}}(47.9,43.3,31.8,28.4)$ were observed. The $2 \mathrm{D}$ NMR spectra of 3 showed the ${ }^{1} \mathrm{H}-{ }^{1} \mathrm{H}$ COSY correlations of $\mathrm{H}-5 / \mathrm{H}-6 / \mathrm{H}-7 / \mathrm{H}-8$ and HMBC correlations from NH-1/C-2, C-3, C-4a and C-8a, and those from $\mathrm{H}-3 / \mathrm{C}-2$ and $\mathrm{C}-4$ indicated a 4-hydroxy-2-oxo-1,2,3,4-tetrahydroquinoline-4-carboxylic acid unit in 3 [18], while ${ }^{1} \mathrm{H}-{ }^{1} \mathrm{H}$ COSY correlations of $\mathrm{H}-2^{\prime} / \mathrm{H}-3^{\prime} / \mathrm{H}-4^{\prime} / \mathrm{H}-5^{\prime} / \mathrm{H}-6^{\prime}$ indicated a cyclopentanamine unit in 3 [19]. HMBC correlations from NH-1'/C-9 and C-6 and from H-2'/C-4 determined the 4-hydroxy-2-oxo-1,2,3,4-tetrahydroquinoline-4-carboxylic acid unit connected with the cyclopentanamine unit via a six-membered ring of N-1'-C-2"-C-3-O-C-4-C-9. The planar structure of 3 was thus determined as depicted in Figure 1. Subsequent HPLC separation of $\mathbf{3}$ on a chiral column yielded 3a and $\mathbf{3 b}$ (Figure S36, Supplementary Information) with opposite optical rotations ( $-65.7^{\circ}$ for $3 \mathbf{a}$ and $+63.2^{\circ}$ for $3 \mathbf{b}$ ) and mirrored CD spectra curves (Figure 3). Subsequently, the absolute configurations of $3 \mathbf{a}$ and $\mathbf{3} \mathbf{b}$ were determined by comparison of their experimental and calculated ECD spectra at the b3lyp/6-31g(d) level. As shown in Figure 3, the theoretically calculated ECD of $\left(4 S, 2^{\prime} R, 3^{\prime} R\right)-3$ and $\left(4 R, 2^{\prime} S, 3^{\prime} S\right)-\mathbf{3}$ matched well with the experimental $C D$ of $\mathbf{3 a}$ and $\mathbf{3} \mathbf{b}$, respectively. Thus, the structures of the two enantiomers were given and named as $(-)-\left(4 S, 2^{\prime} R, 3^{\prime} R\right)$-isatisindigoticanine D (3a, Figure 1$)$ and $(+)-\left(4 R, 2^{\prime} S, 3^{\prime} S\right)$-isatisindigoticanine $\mathrm{D}(3 \mathbf{b}$, Figure 1$)$, respectively $[2,3]$.

For our continuous project to explore more anti-inflammatory components from I. indigotica [8,9], compounds $\mathbf{1} \mathbf{a} / \mathbf{1} \mathbf{b}-\mathbf{5} \mathbf{a} / \mathbf{5} \mathbf{b}$ were tested for their inhibitory effects on the NO production in LPS activated RAW 264.7 cells, a primary indicator in assessing inflammatory activities [20]. The results suggested that only $4 \mathbf{a}$ and $4 \mathbf{b}$ exhibited inhibitory activities, with $\mathrm{IC}_{50}$ values of $76.97 \mu \mathrm{M}$ and $65.88 \mu \mathrm{M}$.

Isatisindigoticanine $\mathrm{B}(\mathbf{1})$ is the first example of a $1 \mathrm{H}$-indol-2-one unit connected with a 4-quinolinecarboxylic acid unit and a pyrrolidine unit via a six-membered ring of $\mathrm{C}-3-\mathrm{C}-4-\mathrm{C}-9-\mathrm{N}-1^{\prime \prime}-\mathrm{C}-2^{\prime \prime}-\mathrm{C}-3^{\prime}$. On the basis of its unique structural features, the putative biosynthetic pathways for isatisindigoticanine B (1) are proposed in Figure 4. The biosynthetic precursor of $\mathbf{1}$ is proposed from $1 H$-indol [4]. First, $1 H$-indol was connected with methionine moiety by sequential or simultaneous enzymatic catalysis to give $1 \mathrm{c}$ [4,5], and then $\mathbf{1} \mathbf{c}$ was modified via an enzyme-catalyzed reaction to give $\mathbf{1 d}$ [20]. Then, $\mathbf{1 e}$ was obtained by cyclization reaction of $\mathbf{1 d}$ [8] and then changed via a reduction reaction to give $\mathbf{1 f}$, and finally $\mathbf{1} \mathbf{f}$ was modified by steps of dehydration and cyclization reactions $[5,8]$ to give $\mathbf{1}$. Compound $\mathbf{1}$ was separated by chiral analysis to give $\mathbf{1} \mathbf{a}$ and $\mathbf{1} \mathbf{b}[2,3]$.

\section{Experimental Section}

The general experimental procedures and extraction and isolation sections are listed in the Supplementary Information section. The plant material (I. indigotica roots) was used in the same way we described previously $[8,9]$. 


\subsection{Physical and Spectroscopic Data of Isatisindigoticanines B-D}

Isatisindigoticanine B (1), a primrose yellow amorphous power; IR (KBr) $v_{\max }: 3407,2923,1720$,

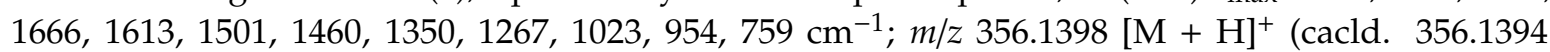
$\left.[\mathrm{M}+\mathrm{H}]^{+}\right) ;{ }^{1} \mathrm{H}$ NMR (DMSO- $\left.d_{6}, 600 \mathrm{MHz}\right)$ and ${ }^{13} \mathrm{C}$ NMR (DMSO- $\left.d_{6}, 150 \mathrm{MHz}\right)($ Table 1$) ;[\alpha]_{D}^{20}$ $+12.6^{\circ}$ ( c 0.15, MeOH) for $(+)-\left(3^{\prime} R, 2^{\prime \prime} S\right)$-isatisindigoticanine B (1a) and $[\alpha]_{D}^{20}-12.5^{\circ}(c 0.07, \mathrm{MeOH})$ for $(-)-\left(3^{\prime} S, 2^{\prime \prime} R\right)$-isatisindigoticanine B (1b).

Isatisindigoticanine $C(2)$, a white amorphous power; IR (KBr) $v_{\max }$ : 3420, 2939, 1636, 1598, 1514, 1461, 1261, 1139, 1025, 859, $813 \mathrm{~cm}^{-1} ; \mathrm{m} / z$ 233.0771 [M - H] ${ }^{-}\left(\right.$cacld. $\left.233.0775[\mathrm{M}-\mathrm{H}]^{-}\right) ;{ }^{1} \mathrm{H} \mathrm{NMR}$ $\left(\mathrm{DMSO}-d_{6}, 600 \mathrm{MHz}\right)$ and ${ }^{13} \mathrm{C}$ NMR (DMSO- $\left.d_{6}, 150 \mathrm{MHz}\right)$ (Table 1$) ;[\alpha]_{D}^{20}-31.1^{\circ}(c 0.21, \mathrm{MeOH})$ for $(-)-\left(2^{\prime} R\right)$-isatisindigoticanine $\mathrm{C}(\mathbf{2 a})$ and $[\alpha]_{D}^{20}+33.1^{\circ}(c 0.13, \mathrm{MeOH})$ for $(+)-\left(2^{\prime} S\right)$-isatisindigoticanine $\mathrm{C}(\mathbf{2 b})$.

Isatisindigoticanine $\mathrm{D}(3)$, a white amorphous power; IR $(\mathrm{KBr}) v_{\max }: 3363,2924,1703,1667$, 1514, 1443, 1408, 1260, 1026, 957, $726 \mathrm{~cm}^{-1} ; \mathrm{m} / \mathrm{z} 273.1245[\mathrm{M}+\mathrm{H}]^{+}$(cacld. $\left.273.1239[\mathrm{M}+\mathrm{H}]^{+}\right)$; ${ }^{1} \mathrm{H}$ NMR (DMSO- $d_{6}, 600 \mathrm{MHz}$ ) and ${ }^{13} \mathrm{C}$ NMR (DMSO- $d_{6}, 150 \mathrm{MHz}$ ) (Table 1$) ;[\alpha]_{D}^{20}-65.7^{\circ}$ (c $0.18, \mathrm{MeOH})$ for $(-)-\left(4 S, 2^{\prime} R, 3^{\prime} R\right)$-isatisindigoticanine $\mathrm{D}(3 \mathbf{a})$ and $[\alpha]_{D}^{20}+63.2^{\circ}(c 0.10, \mathrm{MeOH})$ for $(+)-\left(4 R, 2^{\prime} S, 3^{\prime} S\right)$-isatisindigoticanine $\mathrm{D}(3 \mathbf{b})$.

\subsection{ECD Calculation of Compounds $\mathbf{1} \mathbf{a} / \mathbf{1} \mathbf{b}-\mathbf{3 a} / \mathbf{3 b}$}

The conformers of compounds $\mathbf{1} \mathbf{a} / \mathbf{1} \mathbf{b}-\mathbf{3} \mathbf{a} / \mathbf{3 b}$ were obtained using the MM2 force field with ChemBio3D software. Gaussian 09 software was utilized for the semiempirical PM3 quantum mechanical geometry optimizations and the time-dependent density functional theory (TDDFT). ECD was calculated at the b3lyp/6-31g(d) level [20-22]. The ECD spectra conformers of $\mathbf{1 a} / \mathbf{1} \mathbf{b}-\mathbf{3 a} / \mathbf{3 b}$ were obtained using SpecDis 1.62 and were compared with the experimental data; the calculation details are listed in the supporting information (Figures S26-S33).

\subsection{X-ray Crystallography of (+)-(2'S)-isatisindigoticanine C (2b)}

A crystal of $\mathbf{2} \mathbf{b}$ was obtained in $\mathrm{MeOH}$. The crystallographic data of $\mathbf{2} \mathbf{b}$ were obtained with $\mathrm{Cu}$ $\mathrm{K} \alpha(\lambda=1.54178 \AA)$ radiation at $130 \mathrm{~K}$ on a Bruker Apex II CCD diffractometer. The structures were solved by a direct method and refined with the full-matrix least-squares technique using SHELX-2014 software. Nonhydrogen atoms were refined with anisotropic displacement parameters, and hydrogen atoms were placed in calculated positions and refined with a riding model. The flack parameter was 0.15(7) (Figure S37, Supplementary Information). The crystallographic data of $\mathbf{2} \mathbf{b}$ were deposited in the Cambridge Crystallographic Data Centre (CCDC) with deposition number 1941685.

\subsection{Inhibitory Assay of NO Production}

Compounds $\mathbf{1} \mathbf{a} / \mathbf{1} \mathbf{b}-\mathbf{5} \mathbf{a} / \mathbf{5} \mathbf{b}$ were tested for their NO inhibitory effects in the LPS activated RAW 264.7 cells using the previously reported method $[8,9,23]$. The $\mathrm{IC}_{50}$ values showed that only $4 \mathbf{a}$ and $4 \mathbf{b}$ showed inhibitory effects with $\mathrm{IC}_{50}$ values of $76.97 \mu \mathrm{M}$ and $65.88 \mu \mathrm{M}$ (aminoguanidine hydrochloride was used as the positive control, $\left.\mathrm{IC}_{50} 22.67 \mu \mathrm{M}\right)$.

\section{Conclusions}

In this study, six new alkaloids: $(+)-\left(3^{\prime} R, 2^{\prime \prime} S\right)$-isatisindigoticanine $\mathrm{B} \quad(\mathbf{1 a})$, $(-)-\left(3^{\prime} S, 2^{\prime \prime} R\right)$-isatisindigoticanine $\quad \mathrm{B} \quad(\mathbf{1 b}), \quad(-)-\left(2^{\prime} R\right)$-isatisindigoticanine $\quad \mathrm{C} \quad(\mathbf{2 a})$,

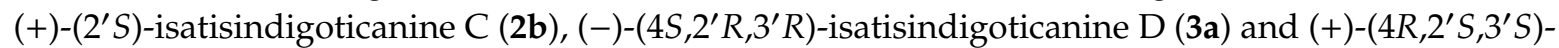
isatisindigoticanine $\mathrm{D}(3 \mathbf{b})$, together with four known ones: (-)-(2R,3R)-3-hydroxy-2Hpyrrolo[2,3-b]indolo[5,5a,6-b,a]quinazoline-9(8H),7'-dione (4a), (+)-(2S,3S)-3-hydroxy-2Hpyrrolo[2-b]indolo[5,5a,6-b,a]quinazoline- $9(8 H), 7^{\prime}$-dione $(4 \mathbf{b})$, epigoitrin (5a) and goitrin (5b), were isolated from the roots of I. indigotica. The alkaloids $\mathbf{1 a}$ and $\mathbf{1 b}$ possess an unpresented carbon skeleton of a $1 \mathrm{H}$-indol-2-one unit connected with a 4-quinolinecarboxylic acid unit and a pyrrolidine 
unit via a six-membered ring of C-3-C-4-C-9-N-1"-C-2"-C-3'. Alkaloids $4 \mathbf{a}$ and $4 \mathbf{b}$ showed NO inhibitory effects in the LPS activated RAW 264.7 cells, with $\mathrm{IC}_{50}$ values of $76.97 \mu \mathrm{M}$ and $65.88 \mu \mathrm{M}$.

Supplementary Materials: The following are available online. Copies of ${ }^{1} \mathrm{H} N M R$ and ${ }^{13} \mathrm{C}$ NMR spectra of 1-5, IR, HREIMS, DEPT $135^{\circ}$, HSQC, HMBC, ${ }^{1} \mathrm{H}-{ }^{1} \mathrm{H}$ COSY spectra of compounds 1-3; ECD calculation details of 1a/1b-3a/3b; Chiral separation chromatography of 1-5; Crystallographic data of $\mathbf{2 b}$.

Author Contributions: R.W., Y.L. and K.C. conducted the experiments; R.X. and K.D. carried out the anti-inflammatory activity experiments; Y.S. collected the ECD data; F.G. analyzed the MS data; D.Z. performed the isolation, analyzed the structures and wrote the paper; R.W. oversaw the research project and drafted the paper.

Funding: This work was supported by the National Natural Science Foundation of China $(81573571,81673570)$, the Excellent Academic Leaders Program of Shanghai (16XD1403500), the programs of the High Level University Innovation Team, the Shanghai E-Research Institute of Bioactive Constituents in Traditional Chinese Medicine and the Shanghai Scientific and Technological Innovation Program (18401931100).

Conflicts of Interest: The authors declare no competing financial interest.

\section{References}

1. Chen, M.H.; Gan, L.S.; Lin, S.; Wang, X.L.; Li, L.; Li, Y.H.; Zhu, C.G.; Wang, Y.A.; Jiang, B.Y.; Jiang, J.D. Alkaloids from the root of Isatis indigotica. J. Nat. Prod. 2012, 75, 1167-1176. [CrossRef]

2. Xi, Y.F.; Zhou, L.; Bai, M.; Wang, J.; Lin, B.; Wang, X.B.; Huang, X.X.; Song, S.J. N-acylanthranilic acid derivatives with anti-A $\beta_{1-42}$ aggregation activity from the leaves of Isatis indigotica fortune. Fitoterapia 2018, 128, 169-174. [CrossRef] [PubMed]

3. Liu, S.F.; Zhang, Y.Y.; Zhou, L.; Lin, B.; Huang, X.X.; Wang, X.B.; Song, S.J. Alkaloids with neuroprotective effects from the leaves of Isatis indigotica collected in the Anhui Province, China. Phytochemistry 2018, 149, 132-139. [CrossRef] [PubMed]

4. Chen, M.H.; Lin, S.; Li, L.; Zhu, C.G.; Wang, X.L.; Wang, Y.A.; Jiang, B.Y.; Wang, S.J.; Li, Y.H.; Jiang, J.D. Enantiomers of an indole alkaloid containing unusual dihydrothiopyran and 1,2,4-thiadiazole rings from the root of Isatis indigotica. Org. Lett. 2015, 45, 1523-7052. [CrossRef] [PubMed]

5. Yang, L.G.; Wang, G.; Wang, M.; Jiang, H.M.; Chen, L.X.; Zhao, F.; Qiu, F. Indole alkaloids from the roots of Isatis indigotica and their inhibitory effects on nitric oxide production. Fitoterapia 2014, 95, 175-181. [CrossRef] [PubMed]

6. Meng, L.J.; Guo, Q.L.; Liu, Y.F.; Shi, J.G. 8,4'-Oxyneolignane glucosides from an aqueous extract of "ban lan gen" (Isatis indigotica root) and their absolute configurations. Acta Pharm. Sin. B 2017, 7, 638-646. [CrossRef] [PubMed]

7. Zhang, D.D.; Li, J.Y.; Shi, Y.H.; Chen, K.X.; Li, Y.M.; Wang, R. Glycosides from roots of Isatis indigotica. Chin. Tradit. Herbal Drugs 2019, 50, 3575-3580.

8. Zhang, D.D.; Li, J.Y.; Ruan, D.Q.; Chen, Z.Q.; Zhu, W.L.; Shi, Y.H.; Chen, K.X.; Li, Y.M.; Wang, R. Lignans from Isatis indigotica roots and their inhibitory effects on nitric oxide production. Fitoterapia 2019, 1-7. [CrossRef]

9. Zhang, D.D.; Du, K.; Zhao, Y.T.; Shi, S.S.; Wu, Y.C.; Jia, Q.; Chen, K.X.; Li, Y.M.; Wang, R. Indole alkaloid glycosides from Isatis tinctoria roots. Nat. Prod. Res. 2019. [CrossRef]

10. Guo, Q.L.; Xu, C.B.; Chen, M.H.; Lin, S.; Li, Y.H.; Zhu, C.G.; Jiang, J.D.; Yang, Y.C.; Shi, J.G. Sulfur-enriched alkaloids from the root of Isatis indigotica. Acta Pharm. Sin. B 2018, 8, 933-943. [CrossRef]

11. Song, X.M.; Zhang, D.D.; He, H.; Li, Y.Z.; Yang, X.J.; Deng, C.; Tang, Z.S.; Cui, J.C.; Yue, Z.G. Steroidal glycosides from Reineckia carnea. Fitoterapia 2015, 105, 240-245. [CrossRef] [PubMed]

12. Zhang, D.D.; Wang, W.; Li, Y.Z.; Li, Z.; Jiang, Y.; Tang, Z.S.; Song, X.M.; Yue, Z.G. Two new pregnane glycosides from Reineckia carnea. Phytochem. Lett. 2016, 15, 142-146. [CrossRef]

13. Li, Y.Z.; Wang, X.; He, H.; Zhang, D.D.; Jiang, Y.; Yang, X.J.; Wang, F.; Tang, Z.S.; Song, X.M.; Yue, Z.G. Steroidal saponins from the roots and rhizomes of Tupistra chinensis. Molecules 2015, 20, 13659-13669. [CrossRef] [PubMed]

14. Cui, Y.W.; Yang, X.J.; Zhang, D.D.; Li, Y.Z.; Zhang, L.; Song, B.; Yue, Z.G.; Song, X.M.; Tang, H.F. Steroidal constituents from roots and rhizomes of Smilacina japonica. Molecules 2018, 23, 798. [CrossRef] [PubMed]

15. Liu, Y.F.; Chen, M.H.; Guo, Q.L.; Lin, S.; Xu, C.B.; Jiang, Y.P.; Li, Y.H.; Jiang, J.D.; Shi, J.G. Antiviral glycosidic bisindole alkaloids from the roots of Isatis indigotica. J. Asian Nat. Prod. Res. 2015, 17, 689-704. [CrossRef] [PubMed] 
16. Hou, W.J.; Sun, H.; Ma, Y.F.; Liu, C.Y.; Zhang, Z.Y. Identification and optimization of novel cathepsin C inhibitors derived from EGFR inhibitors. J. Med. Chem. 2019, 62, 5901-5919. [CrossRef] [PubMed]

17. Cho, J.H.; Chi, H.; Hoi, S. Antimicrobial activity of quinoline derivatives isolated from Ruta chalepensis toward human intestinal bacteria. J. Microbiol. Biotechnol. 2005, 13, 646-651.

18. Feng, C.; Shi, L.; Chen, D.Z.; Zhang, H.C.; Zhao, R.Q. Chemical constituents of effective part in Celosia cristata for treatment of hemostatic. Chin. Tradit. Herbal Drugs 2017, 48, 653-656.

19. Couly, F.; Harari, M.; Dubouilh-Benard, C.; Bailly, L.; Petit, E.; Diharce, J.; Bonnet, P.; Meijer, L.; Fruit, C.; Besson, T. Development of kinase inhibitors via metal-catalyzed C-H arylation of 8-alkyl-thiazolo[5,4-f]-quinazolin-9-ones designed by fragment-growing studies. Molecules 2018, 23, 2181. [CrossRef]

20. Qin, X.J.; Jin, L.; Yu, Y.Q.; Liu, H.; Khan, A.; Yan, H.; Hao, X.J.; An, L.K.; Liu, H.Y. Eucalypglobulusals A-J, formyl-phloroglucinol-terpene meroterpenoids from Eucalyptus globules fruits. J. Nat. Prod. 2018, 81, 2638-2646. [CrossRef]

21. Wang, W.X.; Lei, X.X.; Ai, H.L.; Bai, X.; Li, J.; He, J.; Li, Z.H.; Zheng, Y.S.; Feng, T.; Liu, J.K. Cytochalasans from the Endophytic fungus xylaria cf. curta with resistance reversal activity against fluconazole-resistant candida albicans. Org. Lett. 2019, 21, 1108-1111. [CrossRef] [PubMed]

22. Chen, X.Y.; Zhang, T.; Wang, X.; Hamann, M.T.; Kang, J.; Yu, D.Q.; Chen, R.Y. A chemical investigation of the leaves of Morus alba L. Molecules 2018, 23, 1018. [CrossRef] [PubMed]

23. Zhang, D.D.; Shi, Y.H.; Shi, S.S.; Wu, X.M.; Zhang, L.Q.; Chen, K.X.; Li, Y.M.; Wang, R. Isatisindigoticanine A, a novel indole alkaloid with an unpresented carbon skeleton from the roots of Isatis tinctoria. Nat. Prod. Res. 2019, 1-7. [CrossRef] [PubMed]

Sample Availability: Samples of the compounds $\mathbf{1} \mathbf{a} / \mathbf{1} \mathbf{b}-\mathbf{5} \mathbf{a} / \mathbf{5 b}$ are available from the authors.

(C) 2019 by the authors. Licensee MDPI, Basel, Switzerland. This article is an open access article distributed under the terms and conditions of the Creative Commons Attribution (CC BY) license (http://creativecommons.org/licenses/by/4.0/). 